\title{
China and Ethiopia: Authoritarian affinities and economic cooperation
}

Jean-Pierre Cabestan

Translator. N. Jayaram

(2) OpenEdition

Journals

Electronic version

URL: http://journals.openedition.org/chinaperspectives/6041

DOI: 10.4000/chinaperspectives.6041

ISSN: 1996-4617

Publisher

Centre d'étude français sur la Chine contemporaine

Printed version

Date of publication: 7 December 2012

Number of pages: 53-62

ISSN: 2070-3449

Electronic reference

Jean-Pierre Cabestan, « China and Ethiopia: Authoritarian affinities and economic cooperation», China Perspectives [Online], 2012/4 | 2012, Online since 01 December 2015, connection on 28 October 2019. URL : http://journals.openedition.org/chinaperspectives/6041; DOI : 10.4000/chinaperspectives.6041

(C) All rights reserved 


\title{
China and Ethiopia:
}

\section{Authoritarian affinities and}

\section{economic cooperation}

\author{
JEAN-PIERRE CABESTAN
}

\begin{abstract}
Since 1995, China and Ethiopia have gradually forged close relations. On both sides, the establishment of this partnership was motivated as much by diplomatic, strategic, and even ideological considerations as by economic ones. For Beijing, economic and trade cooperation with Addis Ababa is a means rather than an end in itself. For Ethiopia, however, partnership with China mainly serves the internal political and economic purposes of the regime that has been in place since 1991, under Prime Minister Meles Zenawi for 20 years and, since his death in August 2012, under his successor Hailemariam Desalegn. The relationship is characteristic of the special but asymmetrical links Beijing has sought to establish with countries of the South that are strategically important but economically backward. It also illustrates the attraction the "Chinese model" of development holds in Africa and elsewhere.
\end{abstract}

KEYWORDS: China, Ethiopia, Sino-African relations, authoritarian development, Meles Zenawi.

W hy has the China-Ethiopia relationship become so important and so close over the last ten years? From the Chinese government's viewpoint, this country of about 85 million people is largely devoid of raw materials and other wealth above or below the ground, unlike the two Sudans, Nigeria, or Angola. It does have some oil and gas in the eastern desert, the Ogaden, but that is a danger zone: in 2007, nine Chinese workers from the Zhongyuan Petroleum Exploration Bureau were killed (and seven others kidnapped) by the Ogaden National Liberation Front (ONLF). Its minerals are largely unexploited if not unexplored. Moreover, Ethiopia is among the poorest of the least developed economies, standing $157^{\text {th }}$ (out of 169 countries) in the UN human development index, with a per capita GNP of a mere 350 US dollars: ${ }^{(1)}$ even mild drought leads to famines mitigated only by of the state's ability to scramble a response. The effects of the 2008 economic crisis are still felt despite an annual GNP growth rate of 8 to 10 percent between 2000 and 2011 and 11.4 percent in 2010-2011. Further, Ethiopia stands at the heart of the Horn of Africa, an area of high unrest, consisting of a failed state (Somalia), an isolated problem neighbour (Eritrea), a quasi-state (Somaliland), and a newly independent state that has yet to achieve stability (South Sudan). (2)

Nevertheless, China is very much present in Ethiopia and enjoys a close and special relationship with its government. This article will show that, on both sides, the establishment of this partnership was motivated as much by diplomatic, strategic, and even ideological considerations as economic ones. To stretch this hypothesis further, for Beijing's purposes, economic and trade cooperation with Addis Ababa is a means rather than an end in itself. For Ethiopia, however, partnership with China mainly serves the internal political and economic purposes of the regime that has been in place since 1991, under Prime Minister Meles Zenawi for 20 years and, since his death in August 2012, under his successor Hailemariam Desalegn.

Among China's reasons are Addis Ababa being the seat of the African Union's (AU's) headquarters as well as that of the United Nations Economic Commission for Africa (ECA); Ethiopia's position as the second most populous country in the continent after Nigeria, expected to have a population of 170 million by 2050; its regional, even continental role; its strategic location, especially its control of the Blue Nile's source (Lake Tana); the size of its needs in terms of development; and finally its political stability, the government's authoritarian character, and the state's economic centrality. Ethiopia's interest is that China is actively engaged in its economic development and, as elsewhere in Africa, helps opening the game: its loans and infrastructure projects, its accessibility, its affinities with Prime Minister Meles's "Colbertist" development model - all these factors also nurture the partnership.

The relationship is not without difficulties and imbalances that could trip up the rapprochement in the future, or at least cause upsets or diminish its importance. For the moment, though, Beijing is strengthening its presence in Addis Ababa, which Ethiopians like to improperly refer to as "Africa's capital." (3) Ethiopia is part of the group of so-called "Sino-optimist" countries,

I wholeheartedly thank the two anonymous evaluators of this article's initial version. Their comments and criticisms were highly useful.

1. Human Development Report, "The Real Wealth of Nations, Pathways to Human Development," United Nations Development Programme, 2010

2. See the website of Patrick Ferras, director of l'Observatoire de la Corne de l'Afrique (the Horn of Africa Observatory), www.csba-ferras.eu (consulted on 6 November 2012); and a special issue of Sécurité globale (Global Security), No. 18, Winter 2011-2012, devoted to the Horn of Africa.

3. See Delphine Lecoutre, "L'Éthiopie et l'Afrique" (Ethiopia and Africa), in Gérard Prunier (ed.), L'Éthiopie contemporaine (Contemporary Ethiopia), Paris, CFEE - Karthala, 2007, pp. 153-180. 
as against "Sino-pragmatists" and "Sino-pessimists," going by the categories proposed by Seifudein Adem. (4) Ethiopia is now seduced by China's economic success somewhat like, mutatis mutandis, it was attracted in 1920 1930 by the success of Japan, the first non-Western power to modernise. ${ }^{(5)}$

\section{China-Ethiopia relations since 1991: Gradual forging of a special partnership}

Emperor Haile Selassie established diplomatic relations with the People's Republic of China (PRC) in 1970, but the 1974 revolution, which led to the emergence of a regime close to the Soviet Union, provoked a distancing of Addis Ababa-Beijing links until the late 1980s. It was not until the armed opposition victory in 1991, the fall of the Mengistu regime, and the rise to power of the Ethiopian People's Revolutionary Democratic Front (EPRDF) led by Meles Zenawi that bilateral relations began to experience real growth. ${ }^{(6)}$

The EPRDF, which took power with US backing, did not initially give priority to strengthening ties with China. The regime favoured market economy (except in such matters as land ownership and maintenance of state monopolies) and declared its willingness to establish a federal and democratic polity. It was only in 1995, following a long debate over strengthening its hand in dealing with the West, that the regime decided to rebalance its foreign policy in favour of Russia and China. Especially from China, the main leaders of the EPRDF wanted to learn about "socialist market economy" and agricultural development. ${ }^{(7)}$

In October 1995, following his victory in the first democratic elections in Ethiopia, Prime Minister Meles ${ }^{(8)}$ visited China, and President Jiang Zemin stopped over in Addis Ababa as part of an extensive Africa tour six months later. An ambitious Agreement on Trade, Economic and Technical Cooperation (ATEC) was signed. Automatically renewed every three years, the agreement led to the creation in 1998 of a Joint Economic Commission, which meets every other year. The agreement confers "most favoured nation" status on Ethiopia and covers the whole bilateral economic cooperation, be it in the matter of investment promotion through the formation of SinoEthiopian joint ventures or private entities, maritime transport, or exchanges of "technical personnel."

Since then, Sino-Ethiopian links have continued to strengthen. During a meeting in Beijing of the first Forum on China-Africa Cooperation (FOCAC) in 2000, Addis Ababa was chosen to host the second forum in December 2003. Ethiopia thus found itself in a privileged position, which the Meles regime used to promote a close diplomatic partnership between Beijing and Addis Ababa. (9) At the summit attended by Premier Wen Jiabao, several supplementary agreements were signed.

In 2005, Sino-Ethiopian relations genuinely entered a new phase of close diplomatic, political, and economic partnership. This evolution has a direct link to the Meles regime's hardening as well as the strengthening of his powers following the 2005 elections, during which the opposition managed to take a third of the parliament seats, and in the face of rising Western criticism. The election was tainted with numerous irregularities and was accompanied by much violence (at least 200 dead), and led to a rapid deterioration in relations between Ethiopia and its traditional donors (the United States and European Union), which began to attach conditions to, if not suspend, their assistance. ${ }^{(10)}$ Meles then adopted a veritable developmentalist state agenda. And this authoritarian direction was confirmed during the May 2010 elections: the now muzzled, intimidated, and marginalised opposition won just two of the 547 seats in a parliament almost entirely controlled by the EPRDF, which was accused of having established a "one-party state." (11)

\section{A close political partnership}

Since 1995 and even more so in the last ten years, Ethiopia and China have forged a much closer political partnership. Although the term "strategic partnership" has never been used, the relationship does clearly resemble one. For the Ethiopian government, it is a "close relationship" that is bound to play a major role in the country's ambitious development and poverty reduction projects launched in the same era. Moreover, from Addis Ababa's viewpoint, Beijing is more than that: it is a partner that could also share its economic experiences and extend technical assistance as well as diplomatic support. ${ }^{(12)}$ For his part, Meles made many political gestures. In 2006, the Ethiopian parliament lent its support to China's anti-secession law (regarding Taiwan), and as a member of the UN Human Rights Council until 2007, Ethiopia (along with other African countries) helped defeat all motions criticising the Chinese regime.

There are frequent exchanges of leaders' visits. Meles visited China four times, the last in August 2011, and as during his previous visits (1995, 2004, and 2006) was received by top Chinese leaders, including President Hu Jintao. As noted earlier, Premier Wen Jiabao visited Addis Ababa for the second FOCAC session in 2003. Other visits included those of National People's Congress Chairman Wu Bangguo in 2008, Commerce Minister Chen Deming in 2009, and the Chairman of the Chinese People's Political Consultative Conference and no. 4 in the Party, Jia Qingling, in January 2012 for the opening of a new AU headquarters financed and built by China (at a cost of $\$ 200$ million). The two countries' foreign ministers meet regularly, almost once a year. It may be noted, however, that Hu Jintao, who was to have taken part in this inauguration, has never visited Ethiopia.

Exchanges of visits are not limited to the two sides' top leaders but also include delegations of all kinds - commercial, cultural, medical, military, and increasingly visits from provinces, all of which highlights the diversity of cooperation.

Commercial ties have become institutionalised the most rapidly. In 2006, the Ethiopian government signed a major framework agreement on financing with the China EXIM Bank, leading to a rapid rise in the number of Chinese infrastructure projects (discussed later). The framework agreement

4. Seifudein Adem, "China in Ethiopia: Diplomacy and Economics of Sino-Optimism," African Studies Review, Vol. 55, No. 1, April 2012, pp. 143-160.

5. Addis Dilnessa, "Relations between Ethiopia and China: An Ethiopian Perspective," in Abraham Kinfe (ed.), China Comes to Africa: The Political Economy and Diplomatic History of China's Relation with Africa, Addis Ababa, ElIPD, 2005, p. 241.

6. Gedion Gamora and K. Mathews, "Ethio-China Relations: Challenges and Prospects," in Axel Harneit-Sievers, Stephen Marks, and Sanusha Naidu, Chinese and African Perspectives on China in Africa, Kampala, Pambazuka Press, 2010, pp. 93-94.

7. Seifudein Adem, "China in Ethiopia...," op. cit., pp. 145-146.

8. Meles was President from 1991 to 1995 and then Prime Minister until his death in August 2012. In the 1995 Constitution, the president was accorded a mere protocol role.

9. Ai Ping, "Sino-African Relations - Ethiopia in the New Century: A Chinese Perspective," in Kinfe, China Comes to Africa, op. cit., p. 229.

10. Christine Hackenesch, "European Good Governance Policies Meet China in Africa: Insights from Angola and Ethiopia," Working Paper, EDC2020 (European Development Co-operation to 2020), No. 10, February 2011, p. 32.

11. Kjetil Tronvoll, "The Ethiopian 2010 Federal and Regional Elections: Re-establishing the One Party State," African Affairs, Vol. 110, No. 438, 2011, pp. 121-136

12. Ministry of Information, Foreign Affairs and National Security Policy and Strategy, Addis Ababa, November 2002, p. 152, 1. 
requires all exports to China to be overseen by the Commercial Bank of Ethiopia, the largest state-owned financial institution. Ethiopia intends export earnings to help pay back Chinese loans and is adopting an "Angolan model" of financing its development, despite its lack of oil wealth. ${ }^{(13)}$

Exchanges have also extended to inter-party relations, especially between the Chinese Communist Party and the EPRDF. They began in earnest during the Ethiopia visit in February 2000 of Dai Bingguo, then director of the Party's International Liaison Department. They grew further notably with the China visit in May 2002 of Kassu Ilala, then vice-president of the Southern Ethiopian People's Democratic Movement, which joined the EPRDF in 2005. Ilala was also the minister in charge of infrastructure. More recently, in September 2010, Zhang Xuan, deputy secretary of the Party's municipal committee for Chongqing (which established special economic ties with Ethiopia with the opening of a Lifan car factory in Dukem, near Addis Ababa, in 2007), took part in the $8^{\text {th }}$ organisational congress of the EPRDF. A month later, Ai Ping, vice-minister of the Party's international liaison department, led a delegation to Addis Ababa, where the two parties signed a "memorandum on exchange and cooperation between the CPC and the EPRDF." (14) Highlighting their policy convergences, the two parties have developed exchanges on issues such as ruling party organisation and succession strategies. ${ }^{(15)}$

China's embassy in Addis Ababa is particularly active and has direct dealings with most Ethiopian ministries; every year, more than half of the cabinet, led by the prime minister, takes part in the October 1 Chinese national day festivities, a privilege not accorded to any other mission. In another symbolic development, Seyoum Mefsin, who was Ethiopia's foreign minister from 1991 to 2010, was named ambassador to China this year. ${ }^{(16)}$

Relations with China are thus essential for Ethiopia. From Beijing's perspective, Addis Ababa is a valuable regional launch pad. The Chinese Commerce Ministry (which maintains offices independent of the embassy in several countries) and the China-Africa Development Fund (but not the China Exim Bank) have independent representation in Addis Ababa. The Xinhua News Agency, which is very active in Ethiopia, has its regional headquarters for the Horn of Africa in Addis Ababa. Several Chinese scholars, especially from the Institute of African Studies of Zhejiang Normal University, live in the country on a permanent basis. In 2003, during the $2^{\text {nd }}$ FOCAC summit, China decided to accord Ethiopia the Approved Destination Status for Chinese tourists, although visitors are predominantly traders or immigrants rather than visitors with tourism in mind. ${ }^{(17)}$

\section{Cultural cooperation in education and training: Extending China's "soft power"}

Cultural cooperation in the education field is longstanding but has grown rapidly since the middle of the last decade. Largely China-driven, it is mainly aimed at strengthening its economic implantation but also its soft power in Ethiopia. This cooperation is centred on technical cooperation in agriculture, mining, communications, and energy. More recently it was extended to training journalists and senior officials. Thus, every year since 2006, 200 members of national and regional administrations have undertaken short training stints in China; in fact these are more in the nature of study tours for displaying the success of China's rise. It is a strategy to influence Ethiopian elites.

In February 2010, vice-minister of education Li Weihong led a delegation to Ethiopia to inaugurate the country's first Confucius Institute. ${ }^{(18)}$ Based at the Ethio-China Polytechnic College (in which Beijing invested \$30 million) in Addis Ababa, the institute gives free training to not only language teachers
(28 by late 2010) but also Ethiopian diplomats (24) and officials from 19 different ministries, thus imparting the CCP authorities' viewpoint on Chinese civilisation. ${ }^{(19)}$ In 2011, the Confucius Institute in Addis Ababa signed cooperation agreements with three Ethiopian universities in order to set up Chinese language teaching centres (Mekelle University, $780 \mathrm{~km}$ north of the capital, Addis Ababa University, and Hawassa University, $400 \mathrm{~km}$ south of the capital). ${ }^{(20)}$ The number of Ethiopian students trained free in China rose by 47 , to 118 in 2008. ${ }^{(21)}$

Finally, since 2005, Ethiopia has benefited most from a Chinese programme of young volunteers in service to Africa. Numbering 300 in the whole continent and reminiscent of the US "Peace Corps," these volunteers offer free teaching for a year in disciplines as diverse as agronomy, sports, and information technology; they are paid \$200 a month. (22)

\section{A not inconsequential military cooperation}

China-Ethiopia military cooperation is of a not negligible size, even if it is not comparable to that between the United States and Ethiopia, especially since 11 September 2001. Restructured after the conflict with Eritrea in 2000 and now 130,000 strong, the Ethiopian army is considered one of the most experienced and operational military machines in Africa. ${ }^{(23)}$ Apparently Addis Ababa does not hold it against Beijing for having equipped two camps during the conflict with Asmara between 1998 and 2000, in contravention of a UN embargo on the two countries ( $\$ 1$ billion worth of arms to the two countries). In 2005, Prime Minister Meles hosted General Zhu Wenquan, a key commander in charge of the Nanjing military region, and signed an ambitious military cooperation agreement (training, exchange of technologies, and peace-keeping mission). (24)

China now supplies artillery, light armoured vehicles, and troop transport vehicles to the Ethiopian army. Every year it trains an undisclosed number (perhaps ten) of Ethiopian officers. There are regular exchanges of visits: for instance, in June 2010, the Ethiopian armed forces chief of staff, General

13. The Angolan model is based on Chinese allocations of preferential lending guaranteed by a set quantity of oil. China's Engagement of Africa: Preliminary Scoping of African Case Studies:Angola, Ethiopia, Gabon, Uganda, South Africa, Zambia, Centre for Chinese Studies, University of Stellenbosch, November 2007, pp. 23-27.

14. Chinese foreign ministry website, www.fmprc.gov.cn/eng/wjb/zzjg/fzs/gjlb/2984 (consulted on 6 November 2012)

15. Christine Hackenesch, "European Good Governance," op. cit., p. 33.

16. He is said to be out of favour in Addis Ababa, a possible reason for the posting.

17. A large majority of the 12,000 Chinese who entered Ethiopia on tourist visas in 2008 were businessmen or employees of major Chinese companies. Ethiopian Economics Association \& Ethiopian Economic Policy Research Institute, A Survey of the Economic and Trade Relationships between China, India and Ethiopia, Addis Ababa, 15 December 2009, p. 43.

18. Chinese foreign ministry website, www.fmprc.gov.cn/eng/wjb/zzjg/fzs/gjlb/2984 (consulted on 6 November 2012).

19. "Confucius Institute Opens Training for Ethiopian Diplomats," CRI English, 15 May 2012, www.addislive.com/confucius-institute-opens-training-for-ethiopian-diplomats/ (undated; consulted on 6 November 2012).

20. Addis Ababa Confucius Institute, http://english.hanban.org/node_10957.htm (consulted on 7 November 2012).

21. Monika Thakur, Building on Progress? Chinese Engagement in Ethiopia, Johannesburg, SAllA, Occasional Paper, No. 38, July 2009, p. 12.

22. About 100 of them are thought to have served in Ethiopia. See Kenneth King, "China's Cooperation with Ethiopia - - With a Focus on Human Resources," OSSREA Bulletin, Vol. vIII, No. 1, February 2011, pp. 72-88.

23. Ferras, loc. cit., p. 3. 138,000 according to www.indexmundi.com/facts/ethiopia/armed-forcespersonnel (consulted on 15 October 2012).

24. Joshua Eisenman, and Joshua Kurlantzick, "China's Africa Strategy," Current History, May 2006, p. 222. 
Samora Yenus, visited China for the first time and met a number of the People's Liberation Army (PLA) top brass, including the vice-chairman of the central military commission, Xu Caihou, and his counterpart Chen Bingde. (25) In 2007, Ethiopia was one of 14 African countries where the Chinese embassy had a military attaché.

Meanwhile, whereas the Ethiopian armed forces retain large quantities of Soviet equipment (aircraft and tanks), they are modernising with help mainly from the United States, Italy, Russia, and Israel. Their cooperation with China should not be overblown.

\section{Undeniable diplomatic and strategic convergences}

In diplomatic and strategic terms, the two countries share many viewpoints and interests. While a fierce proponent of equality among states, non-interference in the internal affairs of states, and national sovereignty, Ethiopia, like China, is much engaged in the UN system. The two countries play an active role, for instance, in UN peacekeeping operations. Ethiopia has more personnel on the ground: especially in Darfur, Liberia, Burundi, and above all today in the Abyei area on the border between the two Sudans. ${ }^{(26)}$ China is also present in Darfur, Liberia, and the Democratic Republic of Congo (DRC). Ethiopia also contributes to the fight against international terrorism by cooperating with US forces stationed in Djibouti (Combined Joint Task Force - Horn of Africa). This by no means displeases China, which is itself engaged in combating piracy in the Gulf of Aden and is very hostile to political Islam.

China welcomes Ethiopia's regional role, considering it a stabilising one so long as it does not go about formally modifying borders - and for instance forcibly imposing in Eritrea an opening to the sea in the Assab region, as often hinted by some in Addis Ababa. In China's view, Ethiopia's political economic and security presence is welcome in South Sudan, where Beijing quickly adapted to the independence declared on 9 July 2011 by transforming the active consulate it had maintained in Juba into an embassy. Further, using their respective influence, China and Ethiopia worked in close concert (along with the United States, incidentally) in facilitating the signing of an oil agreement between the two Sudans in August 2012.

China has been even more pragmatic with regard to Somaliland, an entity de facto independent of Mogadishu since its unilateral declaration of independence in 1991. Somaliland enjoys close relations with Ethiopia, and Addis Ababa sees in Berbera an alternative outlet to the sea that reduces its near total dependence on Djibouti. Although the Chinese government is attached to well-known principles and is disinclined to recognise the quasistate, it has developed since at least 2010 semi-official relations with the de facto authorities in Hargeisa, capital of Somaliland, to take part in developing the "Berbera corridor," a European Union-financed project. In January that year, Somaliland's civil aviation minister Waran Adde headed an economic and commercial delegation to Beijing to sign an agreement on the modernisation and expansion of Egal International Airport at Hargeisa (named after late president Mohamed Ibrahim Egal), as well as restoration of the capital's road network. (27) Two months later, in March 2010, a major Chinese government and business delegation visited Hargeisa for the first time and met a number of leaders, including the then president of Somaliland, Dahir Rayale. ${ }^{(28)}$ A year later, the Hong Kong-based Chinese oil company PetroTrans, which has a stake in oil and gas exploration in the Ogaden (discussed later), responded to a call for bids to modernise and expand the
Berbera port. (29) Competing with France's Bolloré group but offering a much lower bid and a more attractive "package," the Chinese firm won the bid a few months later, following the first China visit of Somaliland's newly elected president, Ahmed M. Silanyo, in August 2011. Although Beijing and the Xinhua News Agency prudently made no announcement of official meetings, Chinese leaders were very much associated with negotiations. At any rate, trilateral agreements (among China, Somaliland, and Ethiopia) signed during the visit covered the installation of a gas pipeline and an oil pipeline to the Ogaden, construction of a refinery in Berbera, and renovation of the road linking Berbera, Hargeisa, and Tug Wajala, the city on Ethiopia's border. ${ }^{(30)}$

Finally, in 2006 and in 2008-2009 as well as in 2011, the Ethiopian army's role in Somalia was deemed useful by China, especially by those in the PLA who had often expressed frustration at not being able to intervene on the ground to end piracy in the Gulf of Aden. ${ }^{(31)}$

\section{Flourishing but asymmetric economic cooperation}

China's economic and commercial relations with Ethiopia are characteristic of those it has developed with all developing countries that have large populations - and hence a potentially vast domestic market - and enormous infrastructure needs but are devoid of raw materials for export. In this regard, as in the case of Egypt or Pakistan, relations are flourishing but remain highly asymmetric. The asymmetry is less pronounced than in the case of smaller African states (Togo, Sierra Leone, or even Senegal). But unlike Luanda or Khartoum, Addis Ababa cannot for the present at least pay for its extensive purchases by selling products for which Beijing has a strategic need (oil, gas, copper, or timber). As elsewhere in Africa, relations are dominated by a rapidly expanding trade, but with the balance remaining heavily in China's favour, and infrastructure projects only adding to the Chinese trade surplus. Chinese investments as such have had a slow start, but have helped a more recent and still modest rise in Ethiopian exports, especially to China. The Ethiopian government's long-term strategy is to reduce the immense trade deficit and external debt through industrialisation and agriculture development. However, both deficit and debt have continued to pile up, thanks in part to the extent of Chinese assistance, which as elsewhere in Africa has strings attached.

It is clear that in China's case it is not easy to distinguish between what Beijing calls "win-win economic cooperation" and aid. While infrastructure projects include grants and preferential loans, Chinese assistance has gradually diversified since the 2006 FOCAC and especially since the 2009 one, partly taking on board Addis Ababa's criticisms. Nevertheless, the Chinese

25. Xinhua, 28 and 29 June 2010.

26. Ethiopian forces constitute the major part of the United Nations Interim Security Force for Abyei (UNIFSA) deployed since June 2011

27. Somalilandpress, 29 January 2010.

28. Somalilandpress, 9 March 2011.

29. Established by Hong Kong resident John Ching in 1997, this company was selected in 2001 to build the oil pipeline from Khartoum to Port Sudan $(600 \mathrm{~km})$.

30. "Ethiopia + Berbera Port + China deal - change in the Horn?", Ethiopia forums, 12 August 2011, http://ethiopiaforums.com/ethiopia-berbera-port-china-deal-\%E2\%80\%93-change-in-the-horn (consulted on 6 November 2012); "Somaliland says PetroTrans to extend Berbera port," Ethiopia forums, 20 August 2011 http://ethiopiaforums.com/somaliland-says-petrotrans-to-extendberbera-port (consulted on 6 November 2012). These agreements need to be viewed with caution, as feasibility studies have yet to be carried out and their international legality could prove problematic.

31. Remarks by Chen Bingde, commander-in-chief of the People's Liberation Army ground forces in Washington, Reuters, 18 March 2011. 
cooperation model has yet to evolve, inciting Ethiopia to diversify its partnerships as much as possible. ${ }^{(32)}$

\section{China-Ethiopia trade exchanges}

In 2006 China became Ethiopia's main trade partner. Ethiopian and Chinese figures don't tally, but the difference is far more modest than in the case of major trade partners such as South Africa. One reason for this is the shortcomings of Ethiopian statistical machinery.

Ethiopian figures cited by the European Union show that from 2001-2002 to 2009-2010, Beijing-Addis Ababa trade grew more than ten-fold, from $\$ 153$ million to $\$ 1,693$ million, representing 16.5 percent of Ethiopia's foreign trade value. ${ }^{(33)}$ Of course, in 2009-2010, Ethiopia did more trade with the EU as a whole ( $\$ 2.516$ billion or 24.5 percent of its total foreign trade), but it was with China that Ethiopia had the largest deficit: $\$ 1.261$ billion, or more than 20 percent of Addis Ababa's trade deficit and 5.3 percent of its GNP.

Chinese official figures show bilateral trade rocketing from $\$ 100$ million in 2002 (calendar year) to $\$ 1.467$ billion in 2009, Ethiopian imports rising very fast (to $\$ 1.252$ billion against $\$ 96$ million in 2002), but with a somewhat lower deficit of $\$ 1.038$ billion in the latter year. Even if the time lag between the two sets of figures is taken into account, the gap is not that significant: China has emerged as Ethiopia's main source of trade deficit.

By way of comparison, the deficit with the EU in 2009-2010 was just $\$ 871$ million. The United States was far behind, with $\$ 597$ million worth of trade, accounting for a mere 5.8 percent of Ethiopia's foreign trade and enjoying a surplus of $\$ 442$ million. ${ }^{(34)}$

The share of Ethiopian imports from China in Ethiopia's total imports doubled between 2001/02 and 2009/10, rising from 9 percent of the country's total external purchases to 18 percent. Ethiopia mainly buys equipment and machines from China, as do many other countries on the continent (South Africa, Angola, Nigeria, and Sudan); (35) but it also imports rising quantities of electronic and other consumption goods (garments, pharmaceuticals, and edibles).

Exports to China have also grown, to $\$ 216$ million worth in 2009/10 (\$246 million in 2010). Ethiopia mainly sells China coffee, leather, textiles, sesame, and cut flowers.

In an effort to reduce Addis Ababa's trade deficit, the two sides signed an agreement in January 2010 on preferential access for Ethiopian products in the Chinese market: the number of products exported to China tariff-free rose from 130 to 440, or 95 percent of the total. While Ethiopia's trade deficit is structural, the low prices of Chinese products heighten the profound asymmetry in bilateral exchanges. Sino-Ethiopian trade is forecast to reach $\$ 3$ billion by 2015, but it is less likely that Addis Ababa's trade deficit with China will radically narrow in the coming years.

\section{The case of the footwear industry}

With Africa's largest livestock population, Ethiopia has since the 1920s been producing leather, goatskin, and sheepskin. It has an indigenous leather and footwear industry. In 2000-2001, there was a rapid rise in cheap footwear imports from China, risking the collapse of local enterprises. However, while at first the Chinese imports were highly attractive because they were cheap ( $\$ 1$ to $\$ 2$ a pair), they were quickly revealed to be of poor quality and were shunned by Ethiopian buyers. At the same time, with help from the Ethiopian ministry of trade and industry and foreign investment mainly European but also Chinese (some 20 companies) - local leather and footwear enterprises were modernised. They imported high-performance equipment tax free and entered the international market, managing to apply the brakes on external purchases and raising leather exports. ${ }^{(36)}$ More recently, in November 2011, in order to stimulate industry and following the example of many other countries (India, Pakistan, etc.), Ethiopia decided to ban the export of semi-finished skins (tanned but not dyed) destined for footwear production (crust). This step led many new Chinese firms to set up shop in Ethiopia, some with assistance from the China-Africa Development Fund.

The question is whether this success will remain exceptional. Be that as it may, the lesson is that new competition from Chinese imports in a given sector can stimulate enterprises and local production in that sector if there is clear governmental support as well as backing from other investors (Italians in the case of footwear). In other words, this examples shows that African countries' adaptation to the new international economic context depends on state capacity to react and impose negotiation with economic partners, especially in emerging countries, and the quality of local government as well as more generally the climate they are able to offer foreign investors in terms of security and infrastructures (power, transport).

\section{Infrastructure projects}

As with many other (developing) African countries, it is major infrastructure projects that lend high visibility to China's presence in Ethiopia. Between 2001 and 2007, they accounted for 10 percent of all Chinese infrastructure projects in Africa, behind Nigeria (34 percent) and Angola (20 percent) and more than Sudan's share (8 percent). ${ }^{(37)}$ The three major sectors of Chinese activity are roads, energy, and communications. A recent addition is the building of a modern trans-border rail network. Many sectors are deemed a priority in the Ethiopian government's national development strategy. The pattern of approval, financing, and implementation of Chinese infrastructure projects is now well known: the two governments together choose them or a Chinese company wins the bid following a call for tenders; the projects are financed by Chinese banks with commercial loans guaranteed by the government and often at concessional terms (low interest, with

32. Jean-Noël Chaponnière and Jean-Jacques Gabas, "Les relations économiques entre la Chine et l'Afrique subsaharienne" (Economic relations between China and Sub-Saharan Africa), in JeanJacques Gabas and Jean-Noël Chaponnière, Le temps de la Chine en Afrique. Enjeux et réalités au sud du Sahara (China's time in Africa: Challenges and realities south of the Sahara), Paris, Gemdev/Karthala, 2012, pp. 41-69.

33. Ethiopia's fiscal year begins on July 1 .

34. European statistics for calendar year 2010 show China close on the EU's heels with 1.192 billion euros worth of trade with Ethiopia (including 1.003 billion euros worth of exports) against 1.196 billion (and 761 million in exports) for EU-Ethiopia trade. The United States is the third largest partner, with 719 million euros worth of trade in 2010 (exports valued at 627 million euros). Eurostat, European Union, DG Trade, 10 January 2012, http://trade.ec.europa.eu/doclib/docs/ 2011/january/tradoc_147265.pdf (consulted on 6 November 2012); these data correspond with figures cited in the older report of the Ethiopian Economic Association/Ethiopian Economic Policy Research Institute, A Survey of the Economic and Trade Relationships between China, India and Ethiopia, Addis Ababa, 15 December 2009, http://www.fes-ethiopia.org/media/pdf/China\%20 and\%20India\%20and\%20Ethiopia\%20final\%20report.pdf (consulted on 6 November 2012); Chinese annual statistics for different years.

35. Bert Jacobs, "A Dragon or a Dove? A Comparative Overview of Chinese and European Trade with Sub-Saharan Africa," Journal of Current Chinese Affairs, Vol. 40, No. 4, 2011, p. 35.

36. China's Engagement of Africa, op. cit., pp. 65-67.

37. Mary-Françoise Renard, China Trade and FDI in Africa, African Development Bank Group, Working Paper Series, No. 126, May 2011, p. 21, www.afdb.org/fileadmin/uploads/afdb/Documents/Publications/Working 126.pdf (consulted on 6 November 2012) 
a five-year grace period and a grant component of over 35 percent). The projects are almost exclusively carried out by Chinese national or provincial-level state firms, which get the financing directly in whole or in part. Strictly speaking, these are not investments, even though the Ethiopian Investment Agency treats them as such. ${ }^{(38)}$ While Addis Ababa retains some margin of manœuverability in the choice of projects and loan allocations, this freedom is often slim given its position as recipient, even with regard to the number of Chinese workers allocated to each project. ${ }^{(39)}$

As with other African countries, whether or not tenders are called, the Ethiopian government turns to Chinese firms for a series of well-known reasons: the generally lower initial quote, advantageous financing conditions, and quick orders and execution of projects, even if the quality is often poor (especially in the case of roads, bridges, and communications systems). Moreover, different projects may be bundled as a "package."

In Ethiopia as in most African countries, Beijing's loans are mainly channelled through the Export-Import Bank of China (EXIM Bank, 2006 agreement) and to a lesser extent through the China Development Bank (CDB) and the Industrial and Commercial Bank of China (ICBC). The China-Africa Development Fund, established by the CDB in 2007 with a capital of $\$ 5$ billion, also funds some projects, especially in the private sector: glass, cement, or leather factories (see investments).

The financing is sometimes given to Ethiopian public enterprises in charge of implementing projects. But more often it is the Chinese enterprises that are funded.

In 2007, China chose Ethiopia as one of four African partners (the others being Angola, DRC, and Nigeria) allowed to obtain soft loans from Chinese state-owned financial institutions, especially EXIM Bank.

Although the Chinese authorities have been saying over the past few years that the grant part of project financing is as high as 25 percent, a ratio similar to those of OECD and Paris Club countries (but lower than the IMF-recommended 35 percent), the actual amounts are generally treated as confidential, and in Ethiopia's case are insignificant except for road projects (35.8 percent of the $\$ 349$ million allocated) and telecommunications (23.4 percent of the $\$ 1.4$ billion allocated). For the two hydroelectric projects in which China is engaged ( $\$ 400$ million and $\$ 470$ million), the grant part makes up 12 percent. The grace period is about three years (but seven years for roads), and the loans mature at the end of ten years (20 years for roads). Finally, the interest rate for these projects are not all that advantageous (LIBOR + 1.8 percent to 2.35 percent). ${ }^{(40)}$ Beijing does not grant direct budgetary assistance to Addis Ababa, either.

In this context, the financing and construction of the new AU headquarters was both symbolic and an exception. Entirely funded by a Chinese grant of $\$ 200$ million and inaugurated with great pomp in January 2012, it symbolises Sino-African "friendship" and "solidarity" and also aims at showing that Beijing attaches as much importance to the continental organisation as to bilateral relations with individual African capitals, which is far from being the case in reality.

\section{Road projects}

This is perhaps the best known facet of China's presence in Ethiopia. Offering the lowest bids and all too often defying all competition, Chinese companies have over the past ten years prevailed in most tenders for road projects. In 2007, it was estimated that Chinese firms controlled 50 to 60 percent of this sector; in 2011, the Chinese share rose from 70 percent to 80 percent. The financing sources for these projects are diverse (World Bank, EU, African Development Bank, or Ethiopian government), although Beijing grants major assistance in the form of soft loans or indirect financial help to Chinese firms engaged in the country.

\section{Energy projects: Dams and high-tension lines}

China has mainly invested in building hydraulic dams (such as Tekeze, completed in 2009), including highly controversial projects (Gibe III) and high-tension lines. The objective is both political - it is difficult to avoid recalling the Soviet precedent with the Aswan Dam, the construction of which was shunned by the West and international organisations for partly similar (ecological) reasons - and economic: the sale of power in the national market and to neighbouring countries would help Ethiopia repay loans from Chinese banks (EXIM Bank and CDB). In 2011, Ethiopia produced 2,000 megawatts (MW). This is set to rise five-fold to $10,000 \mathrm{MW}$ by 2015. The country's hydroelectric generation capacity is estimated at 40,000 MW, hence the ongoing ambitious projects. Apart from Gibe III, IV, and V, Ethiopia has since 2011 been building the Millennium dam to emerge as eastern Africa's powerhouse. These projects are part of the East African Power Pool launched in 2005.

Gibe III has drawn much criticism: built at the confluence of Gilgel Gibe and Omo rivers, $470 \mathrm{~km}$ southwest of Addis Ababa, it led to the forced displacement of 200,000 rural folk, with adverse effects on the water source of Lake Turkana in northern Kenya, thus putting at risk 300,000 Kenyans' access to water. In August 2011, the UN's World Heritage Committee joined in criticising the project.

In view of these environmental factors, the World Bank and the European Investment Bank, which financed more modest dams on the Omo (Gibe I and II), as well as the African Development Bank have refused to take part in Gibe III. It was thus that China entered the fray: in 2010, the state-owned Dongfang Electric Machinery Company agreed to supply electrical and mechanical equipment (turbines) funded by a $\$ 500$ million ICBC loan. Another Chinese company, with EXIM Bank financing, agreed to build a high-tension line network supplying the capital. However, the main builder in this project is an Italian firm (Salini Costruttori S.p.A), which won the contract from the Ethiopian government without a call for tenders in 2006 and began building the dam at the end of that year. ${ }^{(41)}$

In sum, this example illustrates China's propensity for assisting developing countries by aligning itself with the ambitions of governments in place and turning a deaf ear to objections from abroad and from experts. Of course, these projects constitute a new source of export earnings for Ethiopia. But the financing of the most recent of them as well as farmers' access to hightension lines have to be seen cautiously. Their impact on rural development is therefore open to question.

38. In 2009, the EU delegation in Ethiopia estimated that Chinese investments in the country stood at $\$ 3$ billion (2nd Quarterly Economic Report, 2009).

39. Monika Thakur, Building on Progress?..., op. cit.

40. LIBOR: London Interbank Offered Rate. Interviews, IMF, Addis Ababa, April 2011. To compare, Indian preferential loans amounted to $\$ 1.5$ billion in December 2010 (2 percent interest rate, 20 to 25 years' maturity and a five-year moratorium). Its commercial loans totalled $\$ 0.5$ billion (LIBOR $+2.3 \%, 15$ years maturity and a five-year moratorium). Indian Embassy, Addis Ababa, April 2011.

41. International Rivers, "Fact Sheet: Gibe III Dam, Ethiopia," May 2009, www.internationalrivers.org (consulted on 6 November 2012). 


\section{Telecommunications}

China is also highly active in the telecommunications sector. ZTE (ZhongXing Telecommunication Equipment), which entered Ethiopia in 1996, has dominated the market since 2006, when it entered into an agreement with the Ethiopian Telecommunications Corporation. This was made possible by the Chinese government's decision to help ZTE, which had been facing financial difficulties at the time (and was on the verge of bankruptcy). ZTE has since played a vital role in modernising Ethiopia's telecommunications. It has rapidly installed a vast mobile telephone network, with 1.2 million lines in Addis Ababa and eight other cities, and that has provided access to many rural people as well. Between 2007 and 2012, the number of mobile phone users rose from 1 million to 15 million. Ongoing GSM and CDMA network projects would eventually cover 64 percent and 90 percent of the country, respectively. ZTE is also said to have trained about 1,000 Ethiopian engineers. ${ }^{(42)}$

However, the quality of these installations has drawn much criticism. At the initiative of Addis Ababa, which sought to balance its overly constraining dependence on ZTE, a contract was signed in 2010 by Ethiopian Telecom and France Telecom under which the French entity would manage its counterpart. (43) France Telecom's entry and its oversight of ETC's modernisation projects helped strengthen the Ethiopian firm's hand in imposing more rigorous norms and quality control on ZTE. This management change offers an interesting but rather exceptional case of a recipient's capacity to react and adjust to a situation perceived as too unbalanced and detrimental.

\section{Railways}

Sino-Ethiopian cooperation and partnership in infrastructure projects also include modernisation of Addis Ababa's airport and the building of a national and international rail network of about 2,600 km by 2015 and 5,060 km by 2020 at a total cost of $\$ 6$ billion. ${ }^{(44)}$

It is the Ethiopian government's latest and most ambitious plan. It aims to link 49 cities with the construction of eight main lines and also connect Ethiopian railways with those of the two Sudans and Kenya as well as restore the link with Djibouti. On the anvil since the mid-2000s, the project could not proceed for lack of funds until China stepped in to help. In 2009, Ethiopian Railways Corporation (ERC) called for tenders, and by May 2010, only China had responded. Although India was also interested, it could not bid within the scheduled time. ${ }^{(45)}$

ERC's first target was to rebuild the railway line linking Addis Ababa with Djibouti, whose port accounts for about 70 percent of Ethiopia's external trade. But instead of renovating the old $781 \mathrm{kms}$ of narrow-gauge railway built by the French between 1897 and 1917, a new single track was to be built close to the old one up to the Djibouti border (656 km).

Other projects notably include the rail link from Addis Ababa to Afar, where potassium can be extracted from the Denakil depression near the borders of Ethiopia, Eritrea, and Djibouti. Another is the link between Addis Ababa and Bedele city, west of the capital and one of the main coal mining areas of Ethiopia. But China has yet to show interest in these projects.

Partly because of this, Ethiopia revised its plan in March 2011, the new objective being the construction of 2,395 km of railways by 2015 at a cost of $\$ 4.5$ billion. ${ }^{(46)}$ Eventually the line is to join the networks of the Sudans and Kenya (despite gauge differences).
These infrastructure projects have, however, led to a rapid rise in Ethiopia's borrowings from China, the volume of debt rising from $\$ 46$ million in 2000 2001 to $\$ 1.4$ billion in 2009-2010, or 25 percent of Ethiopia's total debt. According to some estimates, in 2011, China's share had risen to half of Ethiopia's total debt ( $\$ 3$ to $\$ 4$ billion out of $\$ 7$ to $\$ 8$ billion). ${ }^{(47)}$ Having said that, in May 2007, Beijing agreed to write off $\$ 18.5$ million in debts owed by Addis Ababa, a decision that suggests more such relief in the future. ${ }^{(48)}$

\section{Chinese investments as yet modest}

China is not a major investor in Ethiopia - not yet, at any rate: it is in third or fourth place, depending on the years, behind India ( $\$ 2.5$ billion divided among 1,230 projects in June 2010), Saudi Arabia, and the United States.

This is because of difficulties in investing in the country but also due to the Chinese strategy of implantation, which favours infrastructure projects funded through loans and grants and carried out with a major presence of Chinese workers (discussed later) rather than through the creation of enterprises and participation in the Ethiopian economy's productive (and export) sectors. However, under pressure from Addis Ababa and public opinion, things are beginning to change.

By late 2010, Ethiopia was in $8^{\text {th }}$ place among African countries with Chinese investments ( $\$ 368$ million), well below South Africa ( $\$ 4.2$ billion) and Nigeria ( $\$ 1.2$ billion). It should be noted that Chinese investments in Africa in the years 2004-2010, totalling \$13 billion, constituted no more than 4.1 percent of China's direct investments abroad. Chinese investments in Ethiopia represent a mere 0.1 percent of China's total investments abroad (\$317 billion). ${ }^{(49)}$

The volume of Chinese investments is probably greater than this estimate. In fact some of them originate in Hong Kong or tax havens (Cayman or Virgin Islands). But the Ethiopian Investment Agency's figure ( $\$ 3$ billion in 2011) is suspect because it includes, as noted earlier, infrastructure projects but also because it covers investment contracts or agreements rather that amounts actually invested. ${ }^{(50)}$ These variations stem from the slow implementation of projects: in 2009, just 23 percent of projects were operational, representing 10 percent of the total capital invested, hence the distortion in the statistics. ${ }^{(51)}$

The sectors Chinese enterprises have invested in include construction (about two thirds of capital invested), glass and leather industries, automobiles, and to a lesser extent textiles and agriculture. The rapid rise in Chinese investments in 2009 was due to the construction of two major cement factories, totalling nearly $\$ 600$ million.

42. Zhao Lili, "Contributing to the Development of Ethiopia with Wisdom and Strength," ZTE.com.cn, wwwen.zte.com.cn/endata/magazine/ztetechnologies/2009year/no6/articles/200906/t2009061 2_172517.html (consulted on 6 November 2012).

43. Élodie René, "ZTE, France Telecom et ETC: une coopération win-win-win" (ZTE, France Telecom and ETC: A win-win-win cooperation), Outre-terre, Vol. 4, No. 30, 2011, pp. 335-339.

44. Daniel Berhane, "Leaked Info: Railway To Link 49 Ethiopian Towns," http://danielberhane.wordpress.com/2010/11/14/leaked-info-railway-to-link-49-ethiopian-towns (consulted on 6 November 2012).

45. Interviews, Addis Ababa, April 2010.

46. Ezega, 30 March 2011; Reuters, 14 January 2012.

47. Ibid.

48. China's Engagement of Africa..., op. cit., p. 62.

49. 2010 Statistical Bulletin of China's Outward Foreign Direct Investment, pp. 88-90.

50. Gedion Gamora, Kidist Mulugeta, Kay Mathews, and Hong Yonghong, "The Implementation of the 'Nine Principles' by Chinese Companies in Ethiopia," in Stephen Marks (ed.), Strengthening the Civil Society Perspective: China's African Impact, Le Cap, Fahamu, 2010, p. 43.

51. "Chinese Investment in Ethiopia," Annex, $2^{\text {nd }}$ Quarterly Economic Report, EU Delegation Ethiopia, 2009, p. 2. 


\section{Eastern Industrial Park}

In 2008, China was given some 200 ha of land at Dukem, $35 \mathrm{~km}$ southeast of Addis Ababa in the Oromia region, to set up a vast special economic zone, the Eastern Industrial Park, expected to extend eventually to 1,000 ha. For China, it is one seven SEZs in Africa (Algeria, Egypt, Nigeria (2), Mauritius, and Zambia). ${ }^{(52)}$ The zone gets funding from a consortium of Chinese public and private enterprises. However, in 2011, Chinese investments in Dukem amounted a mere $\$ 100$ million, despite the Ethiopian government's incentives (low-cost land, cheap labour, and tax exemptions). Unlike the Nigerian and Egyptian SEZs, Dukem exclusively hosts Chinese investments.

\section{China's return to the energy sector}

The tragic circumstances in which China pulled out of this sector in 2007 have been noted. ${ }^{(53)}$ Recent Chinese projects in Somaliland as well as new Ethiopian assurances in terms of security seem to have persuaded Chinese firms to reengage in oil and gas exploration and exploitation in the Ogaden. In July 2011, the Ethiopian mining ministry allotted to the aforementioned Chinese company, PetronTrans, the natural gas fields of Calub and Hilala as well as eight exploration blocs in the area officially called Somali Regional State, after the departure in March of Malaysia's Petronas. PetroTransis expected to invest $\$ 4$ billion in these projects, including the construction of a gas pipeline and an oil pipeline to Berbera, probably with assistance from SinoPec or CNPC

Meanwhile, security problems do not seem to have been fully overcome: in August 2011, the Resolve Ogaden Coalition, a front of the ONFL, renewed its demand that foreign oil companies leave the region; the following month, PetroTrans denied a report that ONFL rebels had attacked a convoy of its technicians that was being escorted by the army, leaving 25 Ethiopian soldiers dead.

In any case, two things are certain. On the one hand, Addis Ababa is determined to do all in its power to facilitate PetroTrans's work: its activities in the Ogaden are now protected by federal authorities' special forces. On the other hand, although diminishing, foreign oil and gas companies continue to run major risks in the zone. ${ }^{(54)}$

\section{Agriculture cooperation}

China has little presence in Ethiopia's agriculture, although it still represents 50 percent of GNP and 85 percent of exports, and employs 80 percent of the workforce. Whereas China has in recent years signed major contracts for leasing land in the DRC and Zambia, for instance (2 million hectares and 2.8 million hectares respectively), it has remained cautious in Ethiopia, perhaps because of the many criticisms that followed agreements to lease land to Saudi Arabian and Indian entities and also due to the presence of several Western partners (Netherlands and Belgium) in floriculture, which has emerged as a new export sector. ${ }^{(55)}$ For the present, China prefers training and technology transfers carried out with the help of development assistance.

\section{Development aid and humanitarian aid}

Unveiled during successive Sino-African summits (FOCAC), China's development assistance to Africa has diversified and intensified. Ethiopia is perhaps one of the very few African countries to benefit from the whole gamut of Chinese "cooperation" programmes, Beijing having only recently adopted the notion of public assistance for development. The assistance focuses on agriculture (irrigation) and medical (hospital) projects. ${ }^{(56)}$

In total, Beijing's direct assistance (in the strict sense) to Addis Ababa remains rather modest given the strength of bilateral political and economic relations. It relates to projects that are small in number but of high symbolic value. In 2006 , it amounted to $\$ 1$ million, or 0.14 percent of total aid received by Ethiopia that year (\$758 million). ${ }^{(57)}$ This is due in part to the size of the assistance Ethiopia receives from traditional donors (US, EU) and also to China's "win-win" strategy of favouring South-South cooperation over conventional aid. Nevertheless, Chinese development assistance in Africa has risen, the volume estimated to rank alongside mid-level donors such as Canada or Italy. ${ }^{(58)}$

\section{"China Model" for Ethiopia?}

The size and diversity of the special partnership China and Ethiopia have forged raises the question of whether China could represent a polity development model for Ethiopia. The question is in fact more complex than it might seem at first.

Like many governments in developing countries, Ethiopia is openly seduced by China's economic success, and Addis Ababa sees in the reforms that Beijing introduced over the past three decades lessons for speeding up its own development: an improvement of the business climate through the opening of special economic zones, a call for foreign investments and a fillip to exports, but also a cautious liberalisation of exchange rates and the financial system as well as gradual and orderly integration with the global economy. Similarly, China's mode of accession to the World Trade Organisation could be useful for Ethiopia. In fact, Ethiopia's Growth Transformation Plan 2010-2015 is inspired largely by the strategies followed by countries such as Malaysia and Singapore since the 1960s; also, its agriculture modernisation programme and mode of state intervention draw on the experiences of Taiwan, South Korea, and more recently, China. Finally, and worryingly, Ethiopia also seems to be interested in the monopolistic practices of Chinese state-owned groups and has blocked any economic liberalisation moves. Beijing, for its part, goes along with this growing enthusiasm for the "Chinese model," not by seeking to "sell" its "turnkey" formula but by issuing numerous invitations to Ethiopia's official, economic, and intellectual elites to visit China, and by actively promoting political and trade relations.

In brief, more than Europe's or America's, it is Asia's development model that constitutes a real attraction for the Ethiopian regime.

But Ethiopia, unlike other African countries (Ghana, Senegal, Zambia, etc.), is

52. See Deborah Brautigam and Xiaoyang Tang, "China's Investments in Special Economic Zones in Africa," in Thomas Farole and Gokhan Akinci (eds.), Special Economic Zones: Progress, Emerging Challenges and Future Directions, Washington DC, World Bank, 2011, pp. 69-100, especially pp. 7677

53. After this incident, the Ethiopian regime launched a military offensive in the Ogaden, which led to a humanitarian crisis and provoked the expulsion of international NGOs.

54. William Davison, "PetroTrans May Face Attack in Ethiopia Oil Search, Group Says," http://www.bloomberg.com/news/2011-08-09/petrotrans-may-face-attack-in-ethiopia-oilsearch-group-says.html (consulted on 6 November 2012).

55. The Economist, 21 May 2009

56. Deborah Braütigam and Xiaoyang Tang, An Overview of China's Agricultural and Rural Engagement in Ethiopia, Washington DC, IFPRI Discussion Paper 01185, May 2012.

57. Alemayehu Geda, "Scoping Study on the Chinese Relation with Sub Saharan Africa: The Case of Ethiopia," AERC Scoping Study, Nairobi, March 2008, pp. 4, 11-12.

58. See South-South Cooperation: Africa and the new forms of development partnership, Economic Development in Africa, Report 2010, United Nations Conference on Trade and Development, New York/Geneva, 2010 
going further in embracing the authoritarian development model China advocates. As a severe critic of "neo-liberalism" raging in the West and of the market's excesses, Meles had nothing but admiration for his country's main Asian partner. His successor, Hailemariam Desalegn, as foreign minister and deputy prime minister in 2010, had openly called for following the "Chinese model." (59) In fact, there are a number of political and institutional convergences between the two countries: the EPRDF's status as the ruling and quasi-single party to which the army is subordinated, land as public property, the hegemonic role of village authorities (kebele) and EPRDF local committees, tight control over political activities and especially over the Internet, not to mention the long imperial and administrative traditions the two countries share.

But these convergences have their limits: the Meles government and the EPRDF have been modelled more on Singapore or Putin's Russia. Through all sorts of intimidations, stronger and more effective than in 2005, Meles managed to weaken and even marginalise the opposition during the May 2010 parliamentary elections. But the EPRDF has no plans, nor any need to steer the regime towards a one-party system. There are many dissuasive factors: the human tragedy that marked the years of Mengistu's regime, the existence of a legal and "loyal" albeit divided opposition, Addis Ababa's desire to speed the return of an affluent diaspora that is often critical of the regime's authoritarian tendency, as well as Ethiopia's persisting dependence on traditional donors such as the United States ( $\$ 1$ billion per year), the EU (\$838 million in the 2008-2013 period), and Japan (\$100 million), and the continuing closeness of its relations with the West, where most Ethiopian students are trained. And much more than China's Communist Party, the EPRDF has to ensure regional ethnic representation to reflect the human mosaic of a country with a federal structure (not only Tigreans and the Amhara, who dominate the political scene, but also the Oromo, the Somalis, the Afars, and the southern people).

China's entry on the Ethiopian scene and its contribution to the country's development has undeniably strengthened the authoritarian regime's hand. Like some other African (or authoritarian) countries, the Ethiopian government has also tried to used its partnership with China as a lever to dissuade the West from applying too much pressure over human rights issues. This was the case after the merely provisional and symbolic suspension of EU assistance following irregularities and violence during the 2005 elections. It has remained the case since 2010 .

But then, the West's hesitation in suspending assistance depends less on China than on the extent of Ethiopia's poverty and on the country's strategic role in East Africa as an ally against terrorist movements or in efforts to stabilise Somalia and now South Sudan.

\section{Difficulties considered minimal}

The Sino-Ethiopian partnership is not without its thorns. They stem in part from the nature and priorities of Beijing's diplomatic and economic activities not only in Ethiopia but in the whole of Africa. They also result from the modalities of Chinese enterprises' implantation in developing countries. In this sense, Ethiopia is no exception. Finally, they are also linked to the difficulties of the local terrain and Addis Ababa's own objectives. However, for the foreseeable future, these difficulties are unlikely to hurt the "Sino-optimism" of the majority of Ethiopians, to use Adem's expression.

First of all, China's cooperation and assistance all too often come with political and economic strings attached and are also opaque. Moreover, China expects its friends in Africa and elsewhere to support it on major interna- tional issues and to observe "omerta" on all touchy subjects (such as human rights and Tibet).

But it is in the economic and commercial areas that China's assistance more directly serves its own interests. Although overall, Chinese cooperation and infrastructure projects directly contribute towards accelerating Ethiopia's development, they are often entrusted, without calling for tenders, to Chinese state entities chosen by Beijing as part its global strategy of boosting the might of these firms in the international arena. Even when tenders are invited and international (especially European) financing is secured, subsidised, and supported by their political authorities, Chinese companies are in a better position to quote a more attractive price and capture the market. Thus, using practices that border on dumping, Chinese enterprises have managed to neutralise competition, especially from Japan and South Korea in the road-building sector. ${ }^{\left({ }^{60}\right)}$ The Ethiopian government's immediate interests are not necessarily threatened by these practices: it is actually able to build more kilometres of roads at a lower cost. But its overall interest is in allowing rather than blocking competition.

Chinese projects also add to Ethiopia's trade deficit and present it with a major cost in financial and at times environmental terms. In fact, as elsewhere, the funding conditions are rarely published and international organisations (IMF and World Bank) admit they have great difficulty finding them out. And due to restrictions it imposes on competitors ("single sourcing"), Chinese cooperation is not necessarily less onerous that that from other partners of Ethiopia, and increases its debt in a way that could prove burdensome in the long term.

Moreover, the most delicate and controversial aspect, common to China's cooperation with developing countries, is that infrastructure projects in Ethiopia are carried out with major Chinese labour input. The enterprises engaged thus give Chinese technicians jobs that are often more attractive than in China and help export excess workforce to other developing countries. They thereby create a well-known problem common to many African countries, and which has the potential to negatively affect Sino-Ethiopian relations.

While official figures showed the presence in Ethiopia of about 20,000 Chinese engineers, technicians, and workers in 2011, those engaged in major projects cited above estimate the actually numbers at 100,000 at least. ${ }^{(61)}$ Although Addis Ababa claims to pay great attention to the numbers of workers engaged in each project, in reality it has a weak hand in imposing its will. Moreover, be they Chinese workers who stay on in Ethiopia at the end of their contracts or those who arrive in the guise of "tourists" to make money, the rapid growth of the Chinese community provokes frequent venting of resentment by local people, who are mostly poor or under-employed. Further, technology transfer falls short of Ethiopian expectations. This is often the case with Chinese enterprises' investment projects. ${ }^{(62)}$ According to several accounts, this has led to a growing frustration that Beijing does not seem to fully appreciate.

The other criticism, in Ethiopia's case, is the poor quality of Chinese-supplied infrastructure, technology, and equipment. Moreover, the Ethiopian government considers actual investment by Chinese enterprises in the manufacturing sector to be too low, despite some positive evolution lately.

59. The Economist, 21 October 2010.

60. Interviews, Addis Ababa, April 2010.

61. In 2007 , the number of Chinese in Ethiopia was estimated at 3,000 to 10,000 or more likely 6,000 to 8,000; China's Engagement of Africa, op. cit., p. 63. For instance, of Sinohydro's 10,000 employees in 2010, just 1,000 were Ethiopians (diplomatic source).

62. Alemayehu Geda and Atenafu Meskel, Impact of China-Africa Investment Relations: Case Study of Ethiopia, EARC, Nairobi, 2009, pp. 21-26. 
Another limitation of Chinese activity is that it favours state entities and official elites: no exception in Ethiopia. Contrary to Western assistance, that from China does not yet cover civil society; it was not until 2010 that Ethiopian NGOs were invited for short trips to China. Some NGO representatives have expressed concern over the nature and modalities of Chinese assistance, but Addis Ababa has blocked all public debate over the issue; criticisms, albeit numerous, are therefore confined to private conversation. ${ }^{(63)}$

Finally, in the diplomatic domain and for the economic and strategic reasons noted above, the close Sino-Ethiopian partnership has not really led to a weakening of Addis Ababa's links with its main partners. Apart from Western countries and Japan, Ethiopia enjoys cordial political relations and close economic, technical, and cultural cooperation with countries of the South such as India, Turkey, Brazil, and Saudi Arabia.

For China too, Ethiopia is not without its frustrations common to Africa. Administrative corruption is less of a problem in Ethiopia than in other African countries. However, the lack of efficiency and dysfunction in the bureaucracy, frequent electricity breakdowns, often defective infrastructure, difficulties in obtaining foreign exchange for enterprises set up in the country, state interference in the choice of local partners, daily problems in communication with the ill-trained local workforce, and the backwardness of economic structures stemming from the Ethiopian way of life pose obstacles to fruitful and harmonious cooperation.

Nevertheless, the Ethiopian experience has also revealed the ability for adaptation and correction of the Chinese partners (in a larger sense) that is often overlooked. This is illustrated by the opening of the Dukmen industrial park and the recent rise in Chinese investment in Ethiopia's export sector. And although there are few indications of this yet, the large-scale recourse to the Chinese workforce could also change, if only because Chinese workers are becoming more expensive and less useful to the extent that Ethiopians, including technicians, are being trained to take over.

\section{Conclusion}

There is no denying that China and Ethiopia have since 1995, and particularly over the last ten years, built an especially close diplomatic and economic partnership and that it is expected to be an enduring one, contributing directly to weakening the influence of other major powers active in the Horn of Africa such as the United States, the EU, and Japan, and curbing the ambitions of other emerging countries such as India. ${ }^{(64)}$

China has clearly raised Ethiopia to a privileged partner status in Africa. But contrary to the dominant pattern, Chinese motivations in the country are not mainly economic: Ethiopia is not among the group of major suppliers of raw material to the "workshop of the world"; above all, the motivations are diplomatic, strategic, and even ideological. Of course, the size of infrastructure and industrial projects also adheres to an economic and commercial logic of promoting Chinese companies' rising might. But for the Chinese authorities, cultivating their counterparts in the second most populous African country, the main power in the sub-region, and host of the African Union headquarters, is also a lever to build its influence on the whole continent. Meles Zenawi's personal role and prestige also contributed to this. And although the Chinese Communist Party is discreet over the issue of exporting its "model," it cannot be indifferent to the Ethiopian regime's admiration for the success of its authoritarian development strategy: it contributes to strengthening or at least safeguarding its international legitimacy and consequently, China's "soft power." Thus, in Ethiopia's case, eco- nomic and commercial cooperation is not so much an end in itself but above all is a means for the Chinese state to realise its objectives.

For the Ethiopian side, partnership with China conforms as much to its domestic as to its international priorities. It contributes to consolidating the EPRDF's hold on the political system and the army, directly favours economic development, diversifies its funding sources, and increases its elbow room in often difficult negotiations with its traditional donors. Historically, this partnership is in some way a continuation and (tardy) success of the strategy of cooperation that Haile Selassie pursued with Japan in the years 1920-1930. This double convergence of interests, domestic and external, political and economic, is present not only between China and Africa but also among most developing and undemocratic countries (in Central Asia, for instance). However, what is exceptional in Ethiopia's case is the strong strategic and even ideological dimension of the partnership.

Nevertheless, questions remain over the extent and the future of this special relationship.

On the one hand, it is important to bear in mind that China has contributed to opening the game but in general has been unable to close it advantageously. Although Hailemariam Desalegn and his party apparently want to pursue the work and policies of Meles, they nevertheless have no wish to transpose the Chinese model without reviewing it, nor do they wish to strengthen more than necessary the strategic collusion with Beijing. For Ethiopia, relations with traditional partners remain vital, although China's entry and method of operation has had a major bearing on development projects. It is unclear as yet whether this new factor will lead Americans and Europeans to review their priorities and see merit in the logic of competition reminiscent of the one that prevailed with the Soviet camp during the Cold War. But in Ethiopia as elsewhere, the issue has already been raised.

On the other hand, as in the rest of Africa, China's presence in Ethiopia is a "double-edged sword." (65) For the present and in the foreseeable future, the Ethiopian government and a section of the country's elite will see it as a welcome and irreplaceable accelerator for development. But the question arises whether in due course, and aware of the risks of over-dependence on Beijing, Addis Ababa would not wish to open out in other directions and distance itself from China. Obviously, such an eventuality depends on several factors, especially internal political changes in both China and Ethiopia. The conclusion that may be drawn from this study is that in its relations with Beijing, Addis Ababa is not in as vulnerable a state as many of its neighbours. In any case, the Chinese as well as other partners of Ethiopia would be mistaken in underestimating the nationalism of a proud and ambitious people who attach the highest priority to emerging from the most extreme poverty and to achieving economic modernisation.

\section{Translated by N. Jayaram.}

I Jean-Pierre Cabestan is Professor and Head, Department of Government and International Studies, Hong Kong Baptist University; Associate Research Fellow, Asia Centre, Paris; and Associate Research Fellow, French Centre for Research on Contemporary China, Hong Kong (cabestan@hkbu.edu.hk).

63. Interviews, Addis Ababa, April 2010. See also Christine Hackenesch, "European Good Governance," op. cit., pp. 30-31.

64. Thierry Bangui, La Chine, un nouveau partenaire de développement en Afrique. Vers la fin des privilèges européens sur le continent noir? (China, a new development partner in Africa: Towards an end to European privileges in the Dark Continent?), Paris, L'Harmattan, 2009.

65. Alex Vines, "China in Africa: A mixed blessing," Current History, Vol. 106, No. 700, May 2007. 